\title{
Enzyme Activities and Nutrient Status in Soil under Ber (Ziziphus mauritiana L.) Plants in Semi-Arid Region of Punjab, India
}

\author{
B.K. Yadav ${ }^{*}$ and Navjot Gupta
}

Punjab Agricultural University, Regional Station, Bathinda-151001, Punjab, India

*Corresponding author

\section{Keywords \\ Dehydrogenase, Acid-phosphatase, Alkaline- phosphatase, Soil nutrient, Semi-arid region}

Article Info

Accepted: 06 December 2017 Available Online: 10 January 2018

\section{A B S T R A C T}

The present study was aimed to evaluate the enzyme activities and nutrient status of ber orchard in semi-arid region of Punjab. Surface $(0-15 \mathrm{~cm})$ soils showed $11.3 \%$ and $26.0 \%$ higher DHA as compared to subsurface $(15-30 \mathrm{~cm})$ and $(30-60 \mathrm{~cm})$ layers, respectively. Like DHA, surface $(0-15 \mathrm{~cm})$ soils showed $10.5 \%$ and $25.0 \%$ higher acid phosphatase as compared to subsurface $(15-30 \mathrm{~cm})$ and $(30-60 \mathrm{~cm})$ soils, respectively. Whereas, in surface soils $(0-15 \mathrm{~cm}) 16.6 \%$ and $20.7 \%$ higher alkaline- phosphatase was reported as compared to subsurface soils $(15-30 \mathrm{~cm})$ and $(30-60 \mathrm{~cm})$, respectively. On an average, $\mathrm{pH}$ ranged from 7.64 to 8.45 with mean value of 8.1 in surface $(0-15 \mathrm{~cm})$ soils. However, it varies from 7.87 to 8.65 with mean value of 8.3 in upper subsurface $(15-30 \mathrm{~cm})$ and from 7.86 to 8.78 with mean value of 8.4 in lower subsurface $(30-60 \mathrm{~cm})$ soils. The EC varies from $0.25-0.59 \mathrm{dSm}^{-1}$ in surface $(0-15 \mathrm{~cm})$ with mean value of $0.35 \mathrm{dSm}^{-1}, 0.21-0.47 \mathrm{dSm}^{-1}$ in sub-surface soils $(15-30 \mathrm{~cm})$ with mean value of $0.31 \mathrm{dSm}^{-1}$ and $0.20-0.38 \mathrm{dSm}^{-1}$ in subsurface $(30-60 \mathrm{~cm})$ soils with mean value of $0.26 \mathrm{dSm}^{-1}$. In surface soils the $\mathrm{CaCO}_{3}$ varies from 1.02 to $2.11 \%$ with mean value $1.57 \%$. The $\mathrm{CaCO}_{3}$ content increased with increase in depth and observed 1.19 to $3.15 \%$ with mean value $2.21 \%$ in subsurface $(15-30 \mathrm{~cm})$ soils, 2.03 to $3.44 \%$ with mean value $2.65 \%$ in subsurface $(30-60 \mathrm{~cm})$ soils. The organic carbon content in soil decreased with increase in soil depth and reported $36 \%$ and $51 \%$ low in subsurface soils $(15-30 \mathrm{~cm})$ and $(30-60 \mathrm{~cm})$ as compared to surface soils $(0-15 \mathrm{~cm})$. The surface soils $(0-15 \mathrm{~cm})$ contains 1.2 and 2.8 times more $\mathrm{P}$ compared to subsurface soils $(15-30 \mathrm{~cm})$ and $(30-60 \mathrm{~cm})$. The $\mathrm{K}$ content was decreased with depth, but no deficiencies were reported. The surface soils $(0-15 \mathrm{~cm})$ contain 1.3 and 1.8 times more $\mathrm{SO}_{4}-\mathrm{S}$ compared to subsurface $(15-30 \mathrm{~cm})$ and $(30-60 \mathrm{~cm})$ soils, respectively. The organic carbon had significantly positive correlation $\left(\mathrm{r}=0.737^{*}, P<0.05\right),\left(\mathrm{r}=0.570^{*}, P<0.05\right)$, ( $\left.\mathrm{r}=0.690^{*}, P<0.05\right)$ with dehydrogenase, acid and alkaline phosphatase, respectively. A significant and positive correlation $\left(\mathrm{r}=0.647^{*}, P<0.05\right)$ of available $\mathrm{P}$ was recorded with organic carbon. A significant and positive correlation of available $\mathrm{K}$ and $\mathrm{SO}_{4}-\mathrm{S}$ was reported with OC $\left(\mathrm{r}=0.758^{*}, P<0.05\right)$ and $\left(\mathrm{r}=0.647^{*}, P<0.05\right)$, respectively. Acid phosphatase showed significant positive correlation $(\mathrm{r}=0.742 *, P<0.05),\left(\mathrm{r}=0.634^{*}\right.$, $P<0.05)$ and $(\mathrm{r}=0.692 *, P<0.05)$ with available soil $\mathrm{P}, \mathrm{K}$ and $\mathrm{S}$, respectively. Like acid phosphatase, alkaline phosphatase also showed positive correlation $\left(\mathrm{r}=0.742^{*}, P<0.05\right.$ for available $\mathrm{P}),\left(\mathrm{r}=0.634^{*}, P<0.05\right.$ for available $\left.\mathrm{K}\right)$ and $\left(\mathrm{r}=0.692^{*}, P<0.05\right.$ for 


\section{Introduction}

Indian Jujube popularly known as ber (Ziziphus mauritiana L.) is a multi-purpose tree mainly grown for its fruits. It is a good source of carotene, vitamins $\mathrm{A}$ and $\mathrm{C}$, and fatty oils (Orwa et al., 2009). Fruits and bark are used to make dye and medicinal preparations (Orwa et al., 2009). It can be grown in arid and semi-arid regions as it thrives under very dry conditions. Soil is a living system that influences the ecosystem balance. At micro level a lot of biological and biochemical processes occurring in soils. Soil enzymes are critical in these processes and release nutrients in different cycles and make elements available for plants. Measurements of soil enzyme activity have been used extensively for assessment of different process occurring in nutrient cycles in soils (Tabatabai and Dick, 2002). Soil enzymes are of microbial and plant origin and their activities show the activity of intracellular and extracellular enzymes and bound enzymes to clay and organic matters. They may correlate well with nutrient availability (Asmar et al., 1994).

These activities are important to determine soil quality under different usages, anthropogenic and non- anthropogenic destruction and different types of habitats (Ajwa et al., 1999; Caldwell et al., 1999; Waldrop, 2000; Grierson and Adams, 2000; Sinsabaugh et al., 2002). Among the soil enzymes, dehydrogenase activity (DHA) has been recognized as an important indicator of the oxidative metabolism in soils and thus of the metabolic activity (Nannipieri et al., 2012), because being exclusively intracellular, it is linked to viable cells. Soil phosphomonoesterase (acid and alkaline phosphatase) activities play an important role in catalyzing the hydrolysis of P-ester bonds binding $\mathrm{P}$ to $\mathrm{C}$ in organic matter, thereby releasing inorganic $\mathrm{P}$ which are assimilable by plants (Pascual et al., 2002). In recent years, studies on enzymes activity have engaged the attention of many researchers. However, most of these studies are confined to agricultural cropping systems (Wright et al., 2005; Mandal et al., 2007; Jannoura et al., 2013) and forest ecosystems (Barbhuiya et al., 2004; Devi and Yadava, 2006; Feng et al., 2009) but, information regarding those under fruit plants in semi-arid region is scarce.

Apart from regular addition of manures and fertilizers, the leaf fall and its incorporation are common in fruit orchards which add residues and substrates, thus promoting enzymes activity which is expected to be more than field crops. However, soil microorganisms existing in deeper soil depth less strongly influenced by $\mathrm{C}$ inputs from litter and rely partly on root-derived $\mathrm{C}$ for maintaining activity and growth. So, it may be hypothesized that the vertical activity of soil micro-organisms would be impacted by root distribution of the fruit plants.

Therefore, the fruit orchards constitute a complex ecological landscape. The hypothesis of the work was that fruit plants could have differential microbial activity in the rhizospheric soil (surface and subsurface), influenced by management practice, such as addition of different manures and fertilizers and their levels (on the basis nutritional need of the fruit plants) as well as quality of litter fall and root exudates. Thus, the objectives of this work were: i) to determine the possible changes in the activity of dehydrogenase and phosphomonoesterase (acid and alkaline) at different layers in the soil profile, and ii) to study vertically dynamics of nutrients at different layers in the soil profile during plant growth. We assume that information generated from this study will help in understanding of microbial/enzymes mediated nutrient dynamics and their management under fruit crops in semi-arid regions. 


\section{Materials and Methods}

\section{General characteristics of the study site}

The ber (Ziziphus mauritiana L.) orchard is located at PAU Regional Station, Bathinda, Punjab, India $\left(30^{\circ} 2^{\prime} \mathrm{N}\right.$ latitude and $74^{\circ} 95^{\prime} \mathrm{E}$ longitude; $202 \mathrm{~m} \mathrm{msl}$ ). The climate of the area is characterized by a large seasonal variation as well as fluctuations both in monthly rainfall and temperature. The district falls in the semiarid region of Punjab having annual average rainfall of $523 \mathrm{~mm}$. Month-wise (May, 2016April, 2017) average value of climatic parameters and total precipitation are presented in Figure 1. In orchards trees were planted, with spacing of $7.5 \mathrm{~m}$ (intra-plant) $\times$ $7.5 \mathrm{~m}$ (between-row). The fertilizer doses applied to the fruit crops are $460 \mathrm{~g} \mathrm{~N}$ tree $^{-1}$. Half of fertilizer dose is applied in first week of August and, half dose of fertilizer is applied after fruit setting. The fruit plants are pruned according to standard recommended procedure, during the second weak of May to maintain canopy area. Farmyard manure (FYM) at the rate of $100 \mathrm{~kg} \mathrm{tree}^{-1}$ is added immediately after pruning. Plant protection measures are adopted as per recommended management practice, if necessary. The soil of the orchards is ploughed 3-4 times a year, and irrigated as and when required. Manual weeding is practiced throughout the year to keep the orchard weed-free.

\section{Soil sampling and analysis}

Soil samples were collected randomly from ber (Ziziphus mauritiana L.) orchard at three depths: 0-15 cm, $15-30 \mathrm{~cm}$ and 30-60 $\mathrm{cm}$ with the help of auger from 4 sides of the trunk under the plant canopy, mixed and prepared a composite sample of each depth, placed in labelled plastic bags and transferred immediately to the laboratory. The samples were passed through 2-mm sieve and divided into two fractions: one fraction for the determination of chemical fractions, which were kept at room temperature and the other fraction for measuring of soil enzyme activities which was stored at $4^{\circ} \mathrm{C}$. Dehydrogenase activity (DHA) in soil was determined using the reduction of $2,3,5$ triphenyltetrazolium chloride (TTC) method (Klein et al., 1971), and the colour intensity was measured at $485 \mathrm{~nm}$ by spectrophotometer. The DHA was expressed as microgram $(\mu \mathrm{g})$ triphenylformazane (TPF) produced per gram $(\mathrm{g})$ dry soil per hour at $37^{\circ} \mathrm{C}$. Acid and alkaline phosphatase activity were estimated following the method reported by Tabatabai and Bremner (1969), after soil incubation with modified universal buffer $(\mathrm{pH}$ 6.5 for acid phosphatase and $\mathrm{pH} 11.0$ for alkaline phosphatase) and p-nitrophenyl phosphate ( $\rho-\mathrm{NP})$ at $37^{\circ} \mathrm{C}$, the produced yellow colour intensity was measured colorimetrically at $440 \mathrm{~nm}$. Acid and alkaline phosphatase activities were expressed as microgram $(\mu \mathrm{g}) \rho$-nitro phenol produced per gram (g) dry soil per hour.

The $\mathrm{pH}$ and EC of the soils were determined in 1:2 soil-water suspensions using a glass electrode $\mathrm{pH}$ meter and conductivity meter respectively (Jackson, 1973). The organic carbon was determined by wet digestion method (Walkley and Black, 1934). The available $\mathrm{P}$ in the soil was extracted by employing Olsen extractant $(0.5 \mathrm{M} \mathrm{NaHCO}$, pH 8.5) as described by Olsen et al., (1954). Available $\mathrm{S}$ was determined by extracting soil samples with $0.15 \% \mathrm{CaCl}_{2}$ (Williams and Steinbergs, 1959) and $\mathrm{S}$ in the extract was estimated by turbidimetric method (Chesnin and Yien, 1951). The available $\mathrm{K}$ was extracted by using neutral ammonium acetate and the content was determined by aspirating the extract into flame photometer (Jackson, 1973). The calcium carbonate in soil was analysed by rapid titration method as described by Piper (2011). Fertility status of macro-nutrients is interpreted as the criteria 
suggested by Arora (2002). For statistical analysis of data, Microsoft Excel software (Microsoft Corporation, USA) was used and significant differences were determined at $\operatorname{LSD}(\mathrm{p}=0.05)$.

\section{Results and Discussion}

\section{Enzymes activity}

Higher dehydrogenase activities were reported in surface soil $(0-15 \mathrm{~cm})$ as compared to subsurface soils $(15-30 \mathrm{~cm})$ and $(30-60 \mathrm{~cm})$ during all growth seasons. It ranges from 3.254.66 with mean value of $3.92 \mu \mathrm{g}$ TPF release $\mathrm{g}^{-1}$ dry soil $\mathrm{h}^{-1}$ in surface $(0-15 \mathrm{~cm}), 3.02-4.04$ with mean value of $3.52 \mu \mathrm{g}$ TPF release $\mathrm{g}^{-1}$ dry soil $\mathrm{h}^{-1}$ in subsurface $(15-30 \mathrm{~cm})$ and 2.49 3.87 with mean value of $3.11 \mu \mathrm{g}$ TPF release $\mathrm{g}^{-1}$ dry soil $\mathrm{h}^{-1}$ in subsurface $(30-60 \mathrm{~cm})$. It is also reported that the surface $(0-15 \mathrm{~cm})$ soils showed $11.3 \%$ and $26.0 \%$ higher DHA compare to subsurface $(15-30 \mathrm{~cm})$ and $(30-$ $60 \mathrm{~cm})$ soils, respectively. However, within subsurface, upper layer $(15-30 \mathrm{~cm})$ soils showed $14 \%$ higher DHA as compared to below layer $(30-60 \mathrm{~cm})$. The maximum DHA was reported at the time of flowering followed by fruit setting and pruning (Table 1). Dehydrogenase is only produced by alive cells (Dick, 1994) and is a good indicator of microbial metabolism in soil (Tabatabai, 1982). Generally, soil enzyme activities were higher in the surface soil $(0-15 \mathrm{~cm})$ as compared to sub surface soils $(15-30 \mathrm{~cm})$ and $(30-60 \mathrm{~cm})$. The results suggest that microbial activity in surface soil was perhaps influenced by the inputs added as well as litter-fall whereas; root exudates and other root related activities were probably the principal governor of microbial activity in subsurface soil. DHA in soil depends on the content of soluble organic carbon and, the increased organic matter in the surface soil enhances the soil enzyme activities (Nannipieri et al., 2012). This result is in agreement with the observation made by Adak et al., (2014). The acid phosphatases varies between 2.36- 3.44 with mean value of $3.0 \mu \mathrm{g}$-NP produced $\mathrm{g}^{-1}$ dry soil $\mathrm{h}^{-1}$ in surface $(0-15 \mathrm{~cm}), 2.11-3.21$ with mean value of $2.7 \mu \mathrm{g}$-NP produced $\mathrm{g}^{-1}$ dry soil $\mathrm{h}^{-1}$ in subsurface $(15-30 \mathrm{~cm})$ and 1.96-3.07 with mean value of $2.4 \mu \mathrm{g} \mu \mathrm{g}$ p-NP produced $\mathrm{g}^{-1}$ dry soil $\mathrm{h}^{-1}$ in subsurface $(30-60 \mathrm{~cm})$. Whereas, the alkaline phosphatase varies between 3.15-4.98 with mean value of $4.0 \mu \mathrm{g}$ $\mathrm{p}$-NP produced $\mathrm{g}^{-1}$ dry soil $\mathrm{h}^{-1}$ in surface $(0-$ $15 \mathrm{~cm}), 2.96-4.43$ with mean value of $3.5 \mu \mathrm{g}$ pNP produced $\mathrm{g}^{-1}$ dry soil $\mathrm{h}^{-1}$ in subsurface (15$30 \mathrm{~cm}$ ) and 2.58-4.22 with mean value of 3.3 $\mu \mathrm{g} \mu \mathrm{g}$ p-NP produced $\mathrm{g}^{-1}$ dry soil $\mathrm{h}^{-1}$ in subsurface $(30-60 \mathrm{~cm})$. Like dehydrogenase activity, acid and alkaline phosphatase activity was also higher in surface soil $(0-15 \mathrm{~cm})$ compare to subsurface soil $(15-30 \mathrm{~cm})$ and $(30-60 \mathrm{~cm})$. The surface $(0-15 \mathrm{~cm})$ soils showed $10.5 \%$ and $25.0 \%$ higher acid phosphatase compare to subsurface (15-30 $\mathrm{cm})$ and $(30-60 \mathrm{~cm})$ soils, respectively. Whereas, in surface soil $(0-15 \mathrm{~cm}) 16.6 \%$ and $20.7 \%$ higher alkaline phosphatase was reported as compared to subsurface soils (15$30 \mathrm{~cm}$ ) and (30-60 cm), respectively (Table 1). Acid and alkaline phosphatases are mainly higher in the surface layer. Alkaline phosphatase activity is derived from microorganisms only, while acid phosphatase is contributed both by plant roots and soilinhabiting microbes (Chhonkar et al., 2007). George et al., (2002) reported a higher rhizospheric phosphatase activity in some agroforestry species. Alkaline reaction of the soil might also have increased alkaline phosphatase activity over acid phosphatase activity. The $\mathrm{pH}$ of the soil solution exerts a strong control on these enzyme activities (Chhonkar et al., 2007).

\section{Soil chemical properties}

The soil properties of the soil exhibited variation with respect to different sampling 
periods and soil depths. On an average, in surface $(0-15 \mathrm{~cm})$ soil, the value of $\mathrm{pH}$ ranged from 7.64 to 8.45 with mean value of 8.1. However $\mathrm{pH}$ increased with increase in soil depth during all sampling period and varies from 7.87 to 8.65 with mean value of 8.3 in subsurface soil $(15-30 \mathrm{~cm})$ and from 7.86 to 8.78 with mean value of 8.4 in subsurface (30$60 \mathrm{~cm}$ ) soil (Table 2). The higher $\mathrm{pH}$ in lower layers could be due to increase in accumulation of exchangeable of cations.

This finding is in agreement with Yadav et al., (2016) who reported increase in soil pH with increase in soil depth. Electrical conductivity values of the soil layers indicated the nonsalinity character of the soil profiles. The EC varies from $0.25-0.59 \mathrm{dSm}^{-1}$ in surface $(0-15$ $\mathrm{cm})$ with mean value of $0.35 \mathrm{dSm}^{-1}, 0.21-0.47$ $\mathrm{dSm}^{-1}$ in sub-surface soil $(15-30 \mathrm{~cm})$ with mean value of $0.31 \mathrm{dSm}^{-1}$ and $0.20-0.38 \mathrm{dSm}^{-1}$ in sub-surface layer $(30-60 \mathrm{~cm})$ with mean value of $0.26 \mathrm{dSm}^{-1}$ (Table 2). In general, the upper layers showed higher EC as compared to lower layers, due to salts released through weathering in the arid/semi-arid regions with limited rainfall are usually deposited at some depth in the soil profile (Table 2). Similar findings were also reported Yadav et al., (2016).

In surface soils, $\mathrm{CaCO}_{3}$ content varies from 1.02 to $2.11 \%$ with mean value $1.57 \%$. The $\mathrm{CaCO}_{3}$ content increased with increase in depth and observed 1.19 to $3.15 \%$ with mean value $2.21 \%$ in subsurface soil $(15-30 \mathrm{~cm})$, 2.03 to $3.44 \%$ with mean value $2.65 \%$ in subsurface soil $(30-60 \mathrm{~cm})$ (Table 2). The surface soil $(0-15 \mathrm{~cm})$ showed low $\mathrm{CaCO}_{3}$ content during all sampling period as compared to subsurface soils $(15-30 \mathrm{~cm})$ and $(30-60 \mathrm{~cm})$, may be due to more microbial and plant root activities in upper layer, resulted in release of many organic substances to dissolve $\mathrm{CaCO}_{3}$ and leach down in lower layers. Many researchers (Landeweert et al., 2001,
Sinsabaugh et al., 2002, Van Scho'll et al., 2008) reported that plant roots and microorganisms can release organic acids and enzymes into the soil solution. Organic carbon content in surface soils $(0-15 \mathrm{~cm})$ ranged from 4.6 to $8.7 \mathrm{~g} \mathrm{~kg}^{-1}$ with an average value of $7.2 \mathrm{~g}$ $\mathrm{kg}^{-1}$, in subsurface soils $(15-30 \mathrm{~cm})$ from 3.0 to $6.6 \mathrm{~g} \mathrm{~kg}^{-1}$ with an average value of $4.6 \mathrm{~g}$ $\mathrm{kg}^{-1}$, in subsurface soils $(30-60 \mathrm{~cm})$ from 2.0 to $4.8 \mathrm{~g} \mathrm{~kg}^{-1}$ with an average value of $3.5 \mathrm{~g}$ $\mathrm{kg}^{-1}$ during all growth seasons (Table 3 ).

The value of organic carbon content in soil decreased with increase in soil depth and reported 36 and 51 per cent low organic carbon in subsurface soil $(15-30 \mathrm{~cm})$ and $(30-$ $60 \mathrm{~cm})$ compare to surface soil $(0-15 \mathrm{~cm})$. The data also showed that the soils of orchard had medium to high level of organic carbon up to $30 \mathrm{~cm}$ depth. The medium to high organic carbon content in soils may be attributed to the proper management such as apply of FYM at the time of pruning, or the inputs of fresh litter and above- or belowground biomass production.

\section{Nutrient availability}

Available $\mathrm{P}$ content varied from 25.45 to $38.54 \mathrm{~kg} \mathrm{ha}^{-1}$ in surface soil layer $(0-15 \mathrm{~cm})$, 16.90 to $34.90 \mathrm{~kg} \mathrm{ha}^{-1}$ in upper subsurface soil $(15-30 \mathrm{~cm})$ and 7.75 to $13.88 \mathrm{~kg} \mathrm{ha}^{-1}$ in lower subsurface soil layer $(30-60 \mathrm{~cm})$ with mean value of $33.2,26.8$ and $11.9 \mathrm{~kg} \mathrm{ha}{ }^{-1}$, respectively (Table 3 ). In general, surface soil $(0-15 \mathrm{~cm})$ and subsurface soil $(15-30 \mathrm{~cm})$ showed medium $\mathrm{P}$ content, whereas low $\mathrm{P}$ content were reported in subsurface soil (30$60 \mathrm{~cm}$ ) during entire growth period. The data also showed that surface soil $(0-15 \mathrm{~cm})$ contains 1.2 and 2.8 times more $\mathrm{P}$ compare to subsurface soils $(15-30 \mathrm{~cm})$ and $(30-60 \mathrm{~cm})$. The higher available $\mathrm{P}$ content in surface soils may be due to high alkaline phosphatase activities which mineralize organically bound P. 
Fig.1 Monthly average value of climatic parameters during May 2016 to April 2017

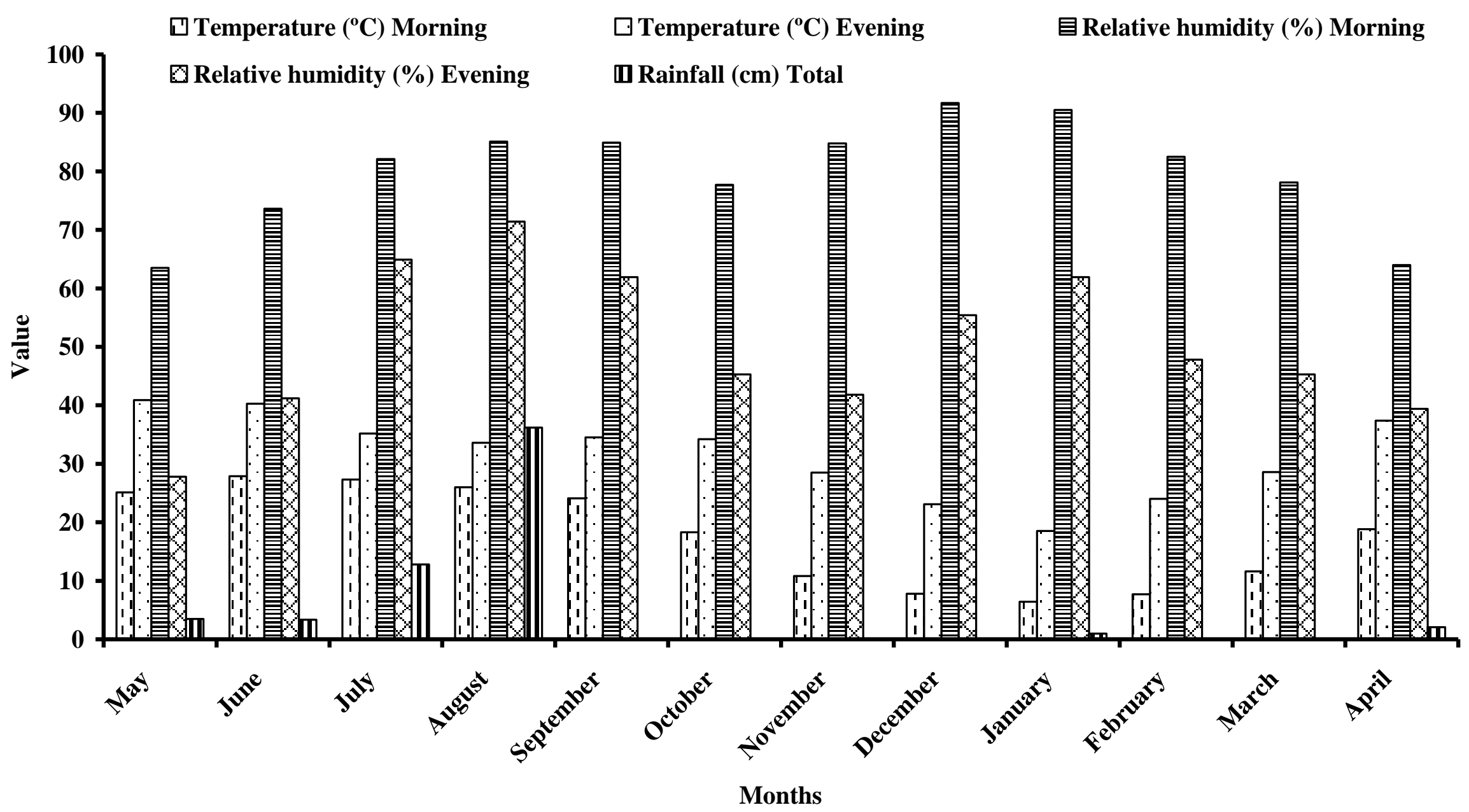


Table.1 Soil dehydrogenase, acid and alkaline phosphatases in rhizosphere soils of ber (Ziziphus mauritiana L.) at different time

\begin{tabular}{|c|c|c|c|c|c|c|}
\hline \multirow[t]{2}{*}{ Soil parameters } & \multicolumn{2}{|c|}{$\begin{array}{c}\text { Dehydrogenase } \\
\left(\mu \mathrm{g} \text { TPF } \mathrm{g}^{-1} \text { dry soil } \mathrm{h}^{-1}\right)\end{array}$} & \multicolumn{2}{|c|}{$\begin{array}{c}\text { Acid phosphatase } \\
\left(\mu \mathrm{g} \text { p-NP g } \mathbf{g}^{-1} \text { dry soil } \mathbf{h}^{-1}\right)\end{array}$} & \multicolumn{2}{|c|}{$\begin{array}{l}\text { Alkaline phosphatase } \\
\left(\mu \mathrm{g} \text { p-NP } \mathrm{g}^{-1} \text { dry soil } \mathrm{h}^{-1}\right)\end{array}$} \\
\hline & Range & Mean* & Range & Mean* & Range & Mean* \\
\hline Sampling depth & \multicolumn{6}{|c|}{ Soil analysis after pruning (May 2016) } \\
\hline $0-15 \mathrm{~cm}$ & $3.25-4.34$ & 3.81 & $2.76-3.22$ & 2.94 & $3.44-3.98$ & 3.87 \\
\hline $15-30 \mathrm{~cm}$ & $3.06-4.39$ & 3.55 & $2.45-3.08$ & 2.68 & $3.01-3.43$ & 3.24 \\
\hline \multirow[t]{2}{*}{$30-60 \mathrm{~cm}$} & $2.67-3.55$ & 3.05 & $2.05-2.87$ & 2.33 & $2.87-3.88$ & 3.11 \\
\hline & \multicolumn{6}{|c|}{ Soil analysis at flowering (September 2016) } \\
\hline $0-15 \mathrm{~cm}$ & $3.87-4.54$ & 4.09 & $2.87-2.59$ & 3.25 & $4.28-4.98$ & 4.66 \\
\hline $15-30 \mathrm{~cm}$ & $3.21-3.98$ & 3.68 & $2.67-3.21$ & 2.98 & $4.01-4.43$ & 4.24 \\
\hline \multirow[t]{2}{*}{$30-60 \mathrm{~cm}$} & 2.87-3.49 & 3.30 & 2.11-3.07 & 2.70 & $3.79-4.22$ & 4.01 \\
\hline & \multicolumn{6}{|c|}{ Soil analysis at fruit setting (November 2016) } \\
\hline $0-15 \mathrm{~cm}$ & $3.65-4.66$ & 4.01 & $2.66-3.44$ & 2.99 & $3.47-4.58$ & 4.14 \\
\hline $15-30 \mathrm{~cm}$ & $3.22-4.04$ & 3.58 & 2.27-3.09 & 2.72 & $3.07-3.96$ & 3.30 \\
\hline \multirow[t]{2}{*}{$30-60 \mathrm{~cm}$} & $2.86-3.87$ & 3.12 & $2.04-2.88$ & 2.37 & $2.88-3.65$ & 3.42 \\
\hline & \multicolumn{6}{|c|}{ Soil analysis after fruit harvesting (April 2017) } \\
\hline $0-15 \mathrm{~cm}$ & $3.55-3.98$ & 3.77 & $2.36-3.22$ & 2.82 & $3.15-3.76$ & 3.48 \\
\hline $15-30 \mathrm{~cm}$ & $3.02-3.69$ & 3.28 & $2.11-3.01$ & 2.48 & $2.96-3.27$ & 3.07 \\
\hline $30-60 \mathrm{~cm}$ & $2.49-3.29$ & 2.95 & $1.96-2.64$ & 2.18 & $2.58-3.09$ & 2.84 \\
\hline
\end{tabular}

*Mean of 10 sampling sites in 2.5 acre orchard

Table.2 Depth wise range and mean value of different soil parameters in rhizosphere soils of ber (Ziziphus mauritiana L.) at different time

\begin{tabular}{|c|c|c|c|c|c|c|c|c|}
\hline \multirow[t]{2}{*}{ Soil parameters } & \multicolumn{2}{|c|}{ pH $(1: 2)$} & \multicolumn{2}{|c|}{$\mathrm{EC}(1: 2) \mathrm{dSm}^{-1}$} & \multicolumn{2}{|c|}{$\mathrm{CaCO}_{3}(\%)$} & \multicolumn{2}{|c|}{ OC $\mathrm{g} \mathrm{kg}^{-1}$} \\
\hline & Range & Mean* & Range & Mean* & Range & Mean* & Range & Mean* \\
\hline Sampling depth & \multicolumn{8}{|c|}{ Soil analysis after pruning (May 2016) } \\
\hline $0-15 \mathrm{~cm}$ & 7.74-8.04 & 7.90 & $0.25-0.59$ & 0.36 & $1.02-2.11$ & 1.56 & $4.6-8.4$ & 6.7 \\
\hline $15-30 \mathrm{~cm}$ & $7.87-8.24$ & 8.08 & $0.22-0.47$ & 0.30 & $1.19-3.15$ & 2.19 & $3.0-5.7$ & 4.1 \\
\hline \multirow[t]{2}{*}{$30-60 \mathrm{~cm}$} & $7.86-8.23$ & 8.11 & $0.20-0.33$ & 0.24 & 2.03-3.44 & 2.66 & $2.0-3.7$ & 3.0 \\
\hline & \multicolumn{8}{|c|}{ Soil analysis at flowering (September 2016) } \\
\hline $0-15 \mathrm{~cm}$ & $7.64-8.02$ & 7.80 & $0.25-0.44$ & 0.33 & $1.12-2.11$ & 1.55 & $5.4-8.7$ & 7.4 \\
\hline $15-30 \mathrm{~cm}$ & $8.12-8.34$ & 8.20 & $0.21-0.39$ & 0.29 & $1.25-2.67$ & 2.17 & $3.7-6.6$ & 4.7 \\
\hline \multirow[t]{2}{*}{$30-60 \mathrm{~cm}$} & $8.16-8.54$ & 8.39 & $0.22-0.36$ & 0.26 & $2.12-3.02$ & 2.67 & 2.3-4.4 & 3.5 \\
\hline & \multicolumn{8}{|c|}{ Soil analysis at fruit setting (November 2016) } \\
\hline $0-15 \mathrm{~cm}$ & $8.12-8.35$ & 8.20 & $0.27-0.44$ & 0.34 & $1.26-1.98$ & 1.56 & $6.5-8.3$ & 7.3 \\
\hline $15-30 \mathrm{~cm}$ & $8.23-8.59$ & 8.34 & $0.25-0.41$ & 0.31 & $1.23-2.78$ & 2.27 & $3.9-5.9$ & 4.8 \\
\hline \multirow[t]{2}{*}{$30-60 \mathrm{~cm}$} & $8.29-8.66$ & 8.56 & $0.21-0.38$ & 0.27 & $2.14-2.98$ & 2.62 & $2.6-4.8$ & 3.7 \\
\hline & \multicolumn{8}{|c|}{ Soil analysis after fruit harvesting (April 2017) } \\
\hline $0-15 \mathrm{~cm}$ & $8.32-8.45$ & 8.40 & $0.31-0.45$ & 0.37 & $1.33-2.03$ & 1.61 & $6.4-7.9$ & 7.2 \\
\hline $15-30 \mathrm{~cm}$ & $8.41-8.65$ & 8.53 & $0.26-0.39$ & 0.32 & $1.28-2.77$ & 2.21 & $4.1-5.9$ & 4.7 \\
\hline $30-60 \mathrm{~cm}$ & $8.48-8.78$ & 8.63 & $0.22-0.35$ & 0.28 & $2.22-3.03$ & 2.65 & $2.6-4.8$ & 3.7 \\
\hline
\end{tabular}

*Mean of 10 sampling sites in 2.5 acre orchard 
Int.J.Curr.Microbiol.App.Sci (2018) 7(1): 479-490

Table.3 Depth wise range and mean value of available nutrients in rhizosphere soils of ber (Ziziphus mauritiana L.) at different time

\begin{tabular}{|c|c|c|c|c|c|c|}
\hline \multirow[t]{2}{*}{ Soil parameters } & \multicolumn{2}{|c|}{$\mathrm{P} \mathrm{kg} \mathrm{ha}^{-1}$} & \multicolumn{2}{|c|}{$\mathrm{K} \mathrm{kg} \mathrm{ha}^{-1}$} & \multicolumn{2}{|c|}{$\mathrm{SO}_{4}-\mathrm{S} \mathrm{kg} \mathrm{ha}{ }^{-1}$} \\
\hline & Range & Mean* & Range & Mean* & Range & Mean* \\
\hline Sampling depth & \multicolumn{6}{|c|}{ Soil analysis after pruning (May 2016) } \\
\hline $0-15 \mathrm{~cm}$ & $25.45-38.54$ & 35.45 & $263.8-390.0$ & 316.5 & $28.3-35.4$ & 31.1 \\
\hline $15-30 \mathrm{~cm}$ & $15.33-34.90$ & 30.87 & $223.0-363.8$ & 273.6 & 21.4-33.1 & 26.0 \\
\hline \multirow[t]{2}{*}{$30-60 \mathrm{~cm}$} & $7.75-12.68$ & 10.78 & $178.8-282.5$ & 228.4 & $15.5-20.0$ & 17.5 \\
\hline & \multicolumn{6}{|c|}{ Soil analysis at flowering (September 2016) } \\
\hline $0-15 \mathrm{~cm}$ & $28.10-33.65$ & 33.79 & $276.3-378.5$ & 316.1 & 27.4-36.9 & 31.6 \\
\hline $15-30 \mathrm{~cm}$ & $15.85-30.13$ & 28.17 & $239.3-354.3$ & 275.4 & 24.9-34.9 & 25.6 \\
\hline \multirow[t]{2}{*}{$30-60 \mathrm{~cm}$} & $9.95-13.35$ & 12.08 & $198.8-287.0$ & 242.1 & $16.4-18.6$ & 17.3 \\
\hline & \multicolumn{6}{|c|}{ Soil analysis at fruit setting (November 2016) } \\
\hline $0-15 \mathrm{~cm}$ & $29.68-38.30$ & 32.19 & $271.8-373.8$ & 318.8 & $29.7-38.5$ & 33.1 \\
\hline $15-30 \mathrm{~cm}$ & $16.90-28.40$ & 24.86 & $248.8-347.3$ & 279.1 & $25.0-33.2$ & 25.8 \\
\hline \multirow[t]{2}{*}{$30-60 \mathrm{~cm}$} & $10.43-13.30$ & 12.27 & $203.8-311.5$ & 247.9 & $17.5-19.7$ & 18.4 \\
\hline & \multicolumn{6}{|c|}{ Soil analysis after fruit harvesting (April 2017) } \\
\hline $0-15 \mathrm{~cm}$ & $27.80-33.58$ & 31.53 & $271.3-378.8$ & 307.1 & 29.6-35.9 & 32.8 \\
\hline $15-30 \mathrm{~cm}$ & $14.73-25.13$ & 23.43 & $243.3-363.3$ & 278.6 & $22.2-31.7$ & 24.9 \\
\hline $30-60 \mathrm{~cm}$ & $10.83-13.88$ & 12.61 & $137.3-292.0$ & 233.7 & $17.2-18.6$ & 17.8 \\
\hline
\end{tabular}

*Mean of 10 sampling sites in 2.5 acre orchard

The data suggested that phosphomonoesterases originating from either plant roots or, micro-organisms had the potential for enhancing $\mathrm{P}$ availability. Medium to high $\mathrm{P}$ content in soils of arid tract of Punjab has been reported by Verma et al., (2005). Yadav et al., (2016) also reported medium $\mathrm{P}$ content in soils of Bathinda district of Punjab.

Status of available $\mathrm{K}$ in the soils ranged from 263.8 to $390.0 \mathrm{~kg} \mathrm{ha}^{-1}$ with an average of $314.63 \mathrm{~kg} \mathrm{ha}^{-1}$ in upper layer $(0-15 \mathrm{~cm})$, whereas it varied from 223.0 to $363.8 \mathrm{~kg} \mathrm{ha}^{-1}$ and 137.3 to $311.5 \mathrm{~kg} \mathrm{ha}^{-1}$ with an average of $276.6 \mathrm{~kg} \mathrm{ha}^{-1}$ and $238.03 \mathrm{~kg} \mathrm{ha}^{-1}$ in lower layers $(15-30 \mathrm{~cm})$ and $(30-60 \quad \mathrm{~cm})$ respectively (Table 3 ). The $\mathrm{K}$ content was decreased with depth, but no deficiencies were reported in soils during the entire growth period. The higher content of available $\mathrm{K}$ is attributed to the prevalence of Illite - a potassium rich mineral in these soils. Moreover, as the ground waters of southwestern district have considerable amount of dissolved potassium, irrigation with such waters also results in higher amounts of available $\mathrm{K}$ in these soils (Patel et al., 2000). These finding are also in line as reported by Verma et al., (2005) and Yadav et al., (2016). The $\mathrm{SO}_{4}-\mathrm{S}$ content in soils varied from 25.3 to $37.5 \mathrm{~kg} \mathrm{ha}^{-1}$ in surface soil $(0-15 \mathrm{~cm}), 17.2$ to $33.1 \mathrm{~kg} \mathrm{ha}^{-1}$ in subsurface soil $(15-30 \mathrm{~cm})$ and 15.5 to $20.2 \mathrm{~kg} \mathrm{ha}^{-1}$ in subsurface soil (30-60 $\mathrm{cm}$ ) with mean value of 32.2, 25.6 and 17.8 $\mathrm{kg} \mathrm{ha}^{-1}$ respectively (Table 3).

Like $P$, the surface soil $(0-15 \mathrm{~cm})$ and subsurface soil $(15-30 \mathrm{~cm})$ showed medium $\mathrm{SO}_{4}-\mathrm{S}$ content, whereas low $\mathrm{SO}_{4}-\mathrm{S}$ content were reported in subsurface soil $(30-60 \mathrm{~cm})$ during entire growth period. The data also showed that surface soil $(0-15 \mathrm{~cm})$ contains 1.3 and 1.8 times more $\mathrm{SO}_{4}-\mathrm{S}$ as compared to 
subsurface $(15-30 \mathrm{~cm})$ and $(30-60 \mathrm{~cm})$ soils, respectively. The results are supported by the findings of Arora et al., (1989) and Bhat et al., (2017).

\section{Relationship between different soil parameters}

Relationship between pooled data of different soil parameters showed that organic carbon had significantly positive correlation $(\mathrm{r}=0$. $\left.737^{*}, P<0.05\right),\left(\mathrm{r}=0.570^{*}, P<0.05\right),(\mathrm{r}=$ $\left.0.690^{*}, P<0.05\right)$ with dehydrogenase, acid and alkaline phosphatase, respectively. This may due to stimulation of microbial population and their activity. Many researchers (Dick, 1994 and Masciandaro et al., 1997) observed the activation of soil micro-organisms by addition of organic matter. These finding are in line with Nannipieri et al., (1983), who reported that organic matter added to soil promote microbial and soil enzyme activities.

A significant and positive correlation $(\mathrm{r}=$ $\left.0.647^{*}, P<0.05\right)$ of available $\mathrm{P}$ was recorded with organic carbon. This relationship might be due to the presence of more $\mathrm{P}$ in organic forms and after the decomposition of organic matter as humus is formed which forms complex with $\mathrm{Fe}$ and $\mathrm{Al}$ and that is a protective cover for $\mathrm{P}$ fixation with $\mathrm{Fe}$ and $\mathrm{Al}$, thus reduce $\mathrm{P}$ adsorption or fixation in soil. Similar results were also reported by Meena et al., (2006), Singh et al., (2014) and Yadav et al., (2016). A significant and positive correlation of available $\mathrm{K}$ and $\mathrm{SO}_{4}-\mathrm{S}$ was reported between $\mathrm{OC}\left(\mathrm{r}=0.758^{*}, P<0.05\right)$ and $\left(\mathrm{r}=0.647^{*}, P<0.05\right)$, respectively. This might be due to creation of favourable soil environment with presence of high organic matter. The increase in $\mathrm{K}$ and $\mathrm{S}$ availability by organic carbon may be accredited to release of $\mathrm{K}$ and $\mathrm{S}$ from organic complexes as well as acidulating action of soil organic carbon thus enhancing the weathering of minerals containing K and S. Pareek (2007) reported significant positive relationship between organic matter and available $S$ in soil. Acid phosphatase showed significant positive correlation $\left(\mathrm{r}=0.742^{*}, P<0.05\right)$, $(\mathrm{r}$ $\left.=0.634^{*}, P<0.05\right)$ and $\left(\mathrm{r}=0.692^{*}, P<0.05\right)$ with available soil $\mathrm{P}, \mathrm{K}$ and $\mathrm{S}$, respectively. Like acid phosphatase, alkaline phosphatase also showed positive correlation $(\mathrm{r}=0.742 *$, $P<0.05$ for available $\mathrm{P}),\left(\mathrm{r}=0.634^{*}, P<0.05\right.$ for available $\mathrm{K})$ and $\left(\mathrm{r}=0.692^{*}, P<0.05\right.$ for available $S$ ). Soil enzymes increased the availability of nutrients by creating favourable condition for mineralization of organic compounds. Phosphatases are involved in transformation of organic and inorganic phosphorus compounds in soil (Amador et al., 1997). Similarly, Moraghebi et al., (2012) reported higher available $\mathrm{N}$ and $\mathrm{P}$ in soil due to higher activity of urease and alkaline phosphatase.

It can be concluded that enzyme activities and nutrient status were strongly influenced by the soil depth. Despite deep rooted nature of fruit crops, microbial biomass and enzymatic activities declined with increase in soil depth. Thus, whether it is fruit crops or field crops, the behaviour of the microbial activities remains unchanged, and more over most of the microbial activities are concentrated within surface soil. The soil $\mathrm{pH}$ and EC of soil suspension (1:2) of all the representative soils was slightly alkaline and non-saline. The surface soil layer have low $\mathrm{CaCO}_{3}$, medium to high organic matter with sufficient amount of macro nutrient $\left(\mathrm{P}, \mathrm{K}\right.$ and $\left.\mathrm{SO}_{4}-\mathrm{S}\right)$. The macro-nutrients analysed decreased with increase in soil depth, however, no deficiency were observed in sub-surface layer. The organic carbon showed significantly positive correlation with dehydrogenase, acid and alkaline phosphatase. Similarly, soil enzyme activities and available soil nutrient also showed significantly positive correlation with each other. 


\section{Acknowledgement}

Authors are thankful to Director, PAU Regional Station, Bathinda for providing all facilities to carry this study.

\section{References}

Adak, T., Singha, A., Kumar, K., Shukla, S.K., Singh, A. and Singh, V.K. 2014. Soil organic carbon, dehydrogenase activity, nutrient availability and leaf nutrient content as affected by organic and inorganic source of nutrient in mango orchard soil. Journal of Soil Science and Plant Nutrition, 14: 394406.

Ajwa, H.A., Dell, C.J. and Rice, C.W. 1999. Changes in enzyme activities and microbial biomass of tallgrass prairie soil as related to burning and nitrogen fertilization. Soil Biology and Biochemistry, 31: 769- 777.

Amador, J.A., Glucksman, A.M., Lyons, J.B., and Gorres, J.H. 1997. Spatial distribution of soil phosphatase activity within a riparian forest Soil Science 162: 808-825.

Arora, C.L. 2002. Analysis of soil, plant and Fertilizer. In: Fundamentals of Soil Science, Indian Society of Soil Science. pp 548

Arora, C.L., Chibba, I.M., Takkar, P.N. and Bara J.S. 1989. Nutrient stastus of soils and plants in some peach orchards of Punjab. Indian Journal of Horticulture 46: 368-375.

Asmar, F., Eiland, F. and Nielsen, N.E. 1994. Effect of extracullaular-enzyme activities on solubilization rate of soil organic nitrogen. Biology and Fertility of Soils, 17:32-38.

Barbhuiya, A.R., Arunachalam, A., Pandey, H.N., Arunachalam, K., Khan, M.L. and Nath, P.C. 2004. Dynamics of soil microbial biomass $\mathrm{C}, \mathrm{N}$ and $\mathrm{P}$ in disturbed and undisturbed stands of a tropical wet evergreen forest. European Journal of Soil Biology, 40: 113-121.

Bhat, Z.A., Akther, F.A., Padder, S.A. Rehman, H.U. and Ganaie, A.Q. 2017. Nutrient status of Grape orchard soils of Jammu and Kashmir, India. International Journal of Agricultural Science and Research, 7: 363-372.

Caldwell, B.A., Griffiths, R.P. and Sollins, P. 1999. Soil enzyme response to vegetation disturbance in two lowland Costa Rican soils. Soil Biology and Biochemistry, 31: 1603-1608.

Chesnin, L. and Yien, C.H. 1951. Turbidimetric determination of available sulphur. Proceedings Soil Science Society of America, 15: 149151.

Chhonkar, P.K., Bhadraray, S., Patra, A.K. and Purakayastha, T.J. 2007. Experiments in Soil Biology and Biochemistry. Westville Publishing House, New Delhi, India. Pp182.

Devi, N.B. and Yadava, P.S. 2006. Seasonal dynamics in soil microbial biomass $\mathrm{C}$, $\mathrm{N}$ and $\mathrm{P}$ in a mixed-oak forest ecosystem of Manipur, North-east India. Applied Soil Ecology 31: 220-227.

Dick, R.P. 1994. Soil enzyme activities as indicators of soil quality. In: Doran, J. W., Coleman, D. C., Bezdicek, D. F., Stewart, B. A., (Eds.) Defining Soil Quality for a Sustainable Environment. Soil Sci. Soc. Am. Madison WI. Pp. 108-123.

Feng, W., Zou, X. and Schaefer, D. 2009. Above and below ground carbon inputs affect seasonal variations of soil microbial biomass in a subtropical monsoon forest of southwest China. Soil Biology and Biochemistry, 41: 978-983.

George, T.S., Gregory, P.J., Wood, M., Read, D. and Buresh, R.J. 2002. Phosphatase activity and organic acids in the 
rhizosphere of potential agroforestry species and maize. Soil Biology and Biochemistry, 34: 1487-1494.

Grierson, P.F. and Adams, M.A. 2000. Plant species affect acid phosphatase, ergosterol and microbial $\mathrm{P}$ in a Jarrah (Eucalyptus marginate Donnex Sm.) forest in south-western Australia. Soil Biology and Biochemistry 32:18171827.

Jackson, M. L. 1973. Soil Chemical Analysis. Prentice Hall of India Pvt. Ltd., New Delhi. Pp 485.

Jannoura, R., Bruns, C. and Joergensen, R.G. 2013. Organic fertilizer effects on pea yield, nutrient uptake, microbial root colonization and soil microbial biomass indices in organic farming systems. European Journal of Agronomy, 49: $32-41$.

Klein, D.A., Loh, T.C. and Goulding, R.L. 1971. A rapid procedure to evaluate dehydrogenase activity of soils low in organic matter. Soil Biology and Biochemistry 3: 385-387.

Landeweert, R., Hofflund E., Finlay R.D. and Van Breemen. N. 2001. Linking plants to rocks: Ectomycorrhizal fungi mobilize nutrients from minerals. Trends in Ecology and Evolution, 16: 248-254.

Mandal, A., Patra, A.K., Singh, D., Swarup, A. and Masto, R.E. 2007. Effect of long-term application of manure and fertilizer on biological and biochemical activities in soil during crop development stages. Bioresource Technology, 98: 3585-3592.

Masciandaro, G., Ceccanti, B. and García, C. 1997. Changes in soil biochemical and cracking properties induced by "living mulch systems". Canadian Journal of Soil Science, 77: 579-587.

Meena, H. B., Sharma, R.P. and Rawat, U.S. 2006. Status of macro-and micronutrients in some soils of Tonk district of Rajasthan. Journal of the Indian Society of Soil Science, 54: 508512.

Moraghebi, F., Matinizadeh, M., Khanjani, S.B., Teimouri, M. and Afdideh, F. 2012. Seasonal variation of urease and alkaline phosphatase activity in natural and artifical habitates of hazel. Journal of Medicinal Plants Research, 6: 27142720.

Nannipieri, P., Giagnoni, L., Renella, G., Puglisi, E., Ceccanti, B., Masciandaro, G., Fornasier, F., Moscatelli, M.C. and Marinari, S. 2012. Soil enzymology: classical and molecular approaches. Biology and Fertility of Soil, 48: 743762.

Nannipieri, P., Muccini, L. and Ciardi, C. 1983. Microbial biomass and enzyme activities: production and persistence. Soil Biology and Biochemistry, 15: 679685.

Olsen, S.R., Cole, C.V., Watanabe, F.S. and Dean, L.A. 1954. Estimation of available phosphorus in soils by extraction with sodium bicarbonate. USDA Circular 939.

Orwa, C., Mutua, A., Kindt, R., Jamnadass, R. and Anthony, S. 2009. Agroforest tree Database: a tree reference and selection guide version 4.0. World Agroforestry Centre, Kenya.

Pareek, N. 2007. Soil mineral is able sulphur a sulphur availability index. Journal of the Indian Society of Soil Science, 55:289-293.

Pascual, J.A., Moreno, J.L., Hernández, T. and García, C. 2002. Persistence of immobilized and total urease and phosphatase activities in a soil amended with organic wastes. Bioresource Technology, 82: 73-78.

Patel, L.B., Verma, V.K., Toor, G.S. and Sharma, P.K. 2000. Beneficial plant nutrient supply from ground waters of arid rract of Punjab. Ecology 
Environment and Conservation, 6: 105108.

Piper C.S. 2011. Soil and Plant Analysis. Scientific Publisher, India pp

Singh, Y.P., Raghubanshi, B.P.S., Tomar, R.S., Verma, S.K. and Dubey, S.K. 2014. Soil fertility status and correlation of available macro and micronutrients in chambal region of Madhya Pradesh. Journal of the Indian Society of Soil Science, 62: 369-375.

Sinsabaugh, R.L., Carreiro, M.M. and Alvarez, S. 2002. Enzyme and microbial dynamics of litter Decomposition. In: Burns R. G., Dick W. A. (Eds) Enzymes in the environment. Marcel Dekker, New York, Pp. 249-266.

Tabatabai, M.A. 1982. Soil enzymes. In: Page, A.L. Miller, R.H. Keeney, D.R. (Eds.) Methods of Soil Analysis Part 2, Agronomy 9, Am. Soc. Agron. Madison Wis. Pp. 903-947.

Tabatabai, M.A. and Dick, W.A. 2002. Enzymes in soil. In: Burns, R.G., Dick, W.A. (Eds) Enzymes in the environment. Marcel Dekker, New York, Pp. 567-596.

Tabatabai, M.A. and Bremner, J.M. 1969. Use of p-nitrophenol phosphate for assay of soil phosphatase activity. Soil Biology and Biochemistry, 1: 301-307.

Van Scho'll, Kuyper, T.W., Smits, M.M., Landeweert, R., Hoffland, E. and van Breemen, N. 2008. Rock-eating mycorrhizas: their role in plant nutrition and biogeochemical cycles. Plant and Soil, PP. 303:35-47.

Verma, V.K., Patel, L.B., Toor, G.S. and Sharma P.K. 2005. Spatial distribution of macronutrients in soils of arid tract of Punjab, India. International Journal of Agriculture and Biology, 7: 295-297.

Waldrop, M.P., Balser, T.C. and Firestone, M.K. 2000. Linking microbial community composition to function in a tropical soil. Soil Biology and Biochemistry, 32: 1837-1848.

Walkley, A. and Black I.A. 1934. An examination of the Degtjareff method for determining soil organic matter and a proposed modification of the chronic acid titration method. Soil Science, 37: 29-38.

Williams, C.H., and Steinbergs, A. 1959. Soil sulphur fractions as chemical indices of available sulphur in some Australian soils. Australian Journal of Agricultural Research 10: 342-352.

Wright, A.L., Hons, F.M. and Matocha, J.E. 2005. Tillage impacts on microbial biomass and soil carbon and nitrogen dynamics of corn and cotton rotations. Applied Soil Ecology, 29: 85-92.

Yadav, B.K., Sidhu, A.S. and Thaman, S. 2016. Soil fertility status of Punjab Agricultural University seed farm, Chak Ruldu Singh Wala, Sangat, Bathinda, Punjab. Annals of Plant and Soil Research, 18:226.231.

\section{How to cite this article:}

Yadav, B.K. and Navjot Gupta. 2018. Enzyme Activities and Nutrient Status in Soil under Ber (Ziziphus mauritiana L.) Plants in Semi-Arid Region of Punjab. Int.J.Curr.Microbiol.App.Sci. 7(01): 479-490. doi: https://doi.org/10.20546/ijcmas.2018.701.057 